\title{
New Designed Thermosyphon Solar Water Heater with Small Sized Parabolic Trough Collectors
}

\author{
Jehad M.Saed ${ }^{1}$, Mohammad J.R. Abdunnabi ${ }^{2}$, Akram A. Essnid ${ }^{3}$, Ahmed M. A. Buishi ${ }^{4}$ \\ ${ }^{1}$ Engineering academy Tajoura,Tripoli-Libya \\ ${ }^{2-4}$ Centre for Solar Energy Research and Studies, Tajoura, Tripoli-Libya
}

e-mail: ${ }^{1} J e h a d-2143 @ e a t . e d u . l y ;{ }^{2}$ _abdunnabi@csers.ly; ${ }^{3}$ sneeda74@yahoo.com; ${ }^{4}$ bouaishi18@gmail.com

\begin{abstract}
In this paper, the performance of thermosyphon solar water heater of small-sized parabolictrough collectors has been experimentally investigated under Libyan climate. The solar collectors were fabricated from the locally available materials. The thermosyphon system consists of two parabolic troughs with $3.16 \mathrm{~m}^{2}$ aperture area and a storage tank of 170 liters. It is erected in the main outdoor testing area at the Center for Solar Energy Research and Studies for thermal performance evaluation. Twenty days of experiments were considered for the analysis of the new system performance. The experimental results showed that the maximum outlet temperature of withdrawn hot water at the end of the day was $73.4{ }^{\circ} \mathrm{C}$ for a daily solar insolation of $27.67 \mathrm{MJ} / \mathrm{m}^{2}$ and diffuse ratio less than $18 \%$ (clear sky). Whereas, the minimum hot water withdrawn temperature was $37^{\circ} \mathrm{C}$ with daily solar insolation of $12.82 \mathrm{MJ} / \mathrm{m}^{2}$ and diffuse ratio over $61 \%$. The system performance decreases as the diffuse ratio increases due to the nature of concentrating technology. The input/output characteristics equation of the system is obtained and the performance is compared with similar systems of the same size and different collection technologies. The compassion showed a competitive performance compared to other technologies.
\end{abstract}

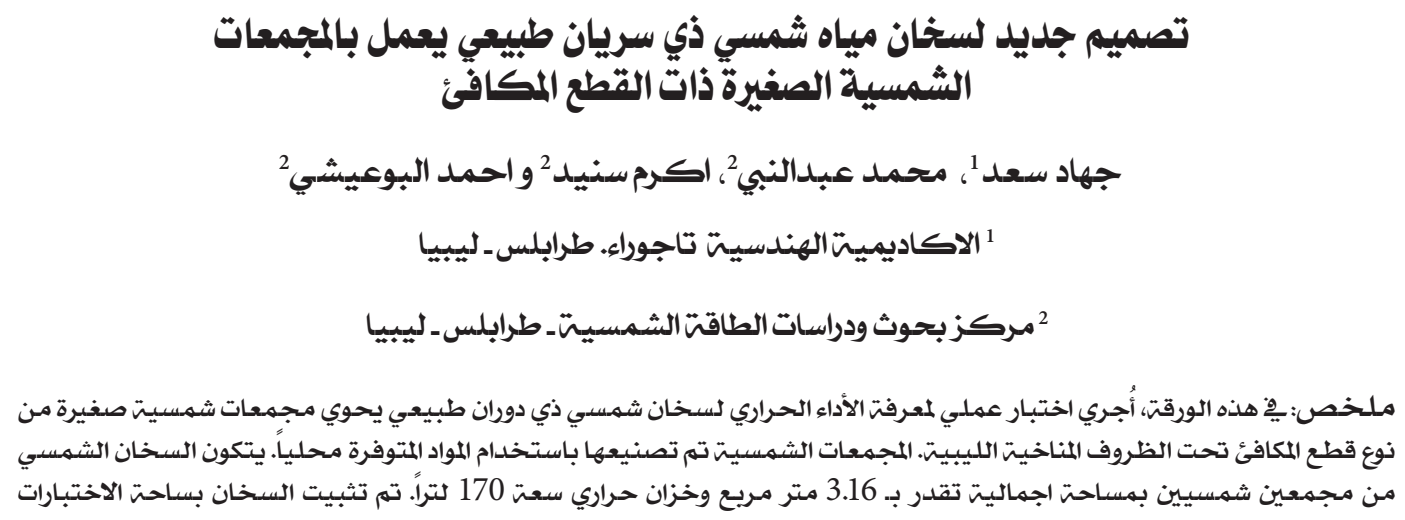




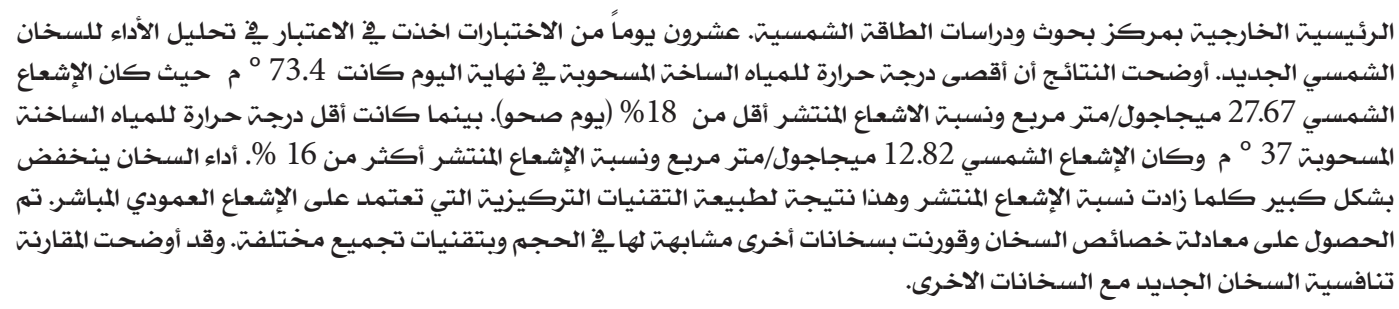

Keywords: Thermosyphon SWHs, Parabolic trough collectors, experimental work, collector manufacturing

\section{INTRODUCTION}

Solar energy technologies have the potential to play a significant role in the world's energy mix. The theoretical solar energy potential on the Earth's surface (land and ocean) has been estimated at $3.9 \times 106 \mathrm{EJ} / \mathrm{yr}$ [1]. This amount of energy is sufficient to meet all energy demand of the world. Libya is one of the countries that have a high solar insolation with an average solar radiation $7.1 \mathrm{kWh} / \mathrm{m}^{2} /$ day on the coast region in the north and $8.1 \mathrm{kWh} / \mathrm{m}^{2} /$ day in the south region [2]. This makes Libya suitable for solar energy applications.

Various technologies of solar water heaters for domestic applications have been in use for decades. Most of these systems were based on non-concentrating technology, such as: flat plate collectors, vacuum tubes, and heat pipes. Concentrating technology is not commonly used in domestic solar water heating applications, it is commonly used for large-scale applications where high temperature is needed.

The intensity of solar radiation received on the earth is very low $\left(1000 \mathrm{~W} / \mathrm{m}^{2}\right)$ and it is not enough to produce high temperature with widely spread nonconcentrating technology. Parabolic concentrators play an important role for focusing solar energy onto a heating area to obtain high temperatures. Various types of concentrators are used for heating and generating electricity applications and most of these applications are utilized in a large-scale. However, solar cooking is an example of small scale application of concentrating technology. Analysis of different types of concentrators has been made as per the desired application and few of them are discussed below.
Manufacturing parabolic trough collectors with local materials for domestic and industrial heating process and evaluating their performance in the local climate is reported by some researchers. $[3,4]$

Arasu and Sornakumar [5] explained the design and manufacturing of smooth 90 rim angle fiberglass-reinforced parabolic trough for water heating application. The total thickness of the parabolic trough is $7 \mathrm{~mm}$. The concave surface where the reflector is fixed is fabricated with high degree of surface finish. It has been found that the standard deviation of the distribution of the parabolic surface errors is 0.0066 radians from the collector performance test according to ASHRAE Standard 93 (1986), which indicates the high accuracy of the parabolic surface. Gang et al. [6] studied solar water heater with compound parabolic concentrator (CPC) U-pipe type, and investigated its performance in meeting higher temperature requirements keeping in mind the fact that the conventional solar water heaters based on flat collectors have low efficiencies in attaining higher temperatures particularly above $50{ }^{\circ} \mathrm{C}$. They also found that such types of systems are not useful for higher temperature applications such as heat powered cooling, building heating, industrial heating, seawater desalination and so on. Therefore they investigated the solar water heater with compound parabolic concentrator (CPC) U-pipe type. They found that when the water is heated from $26.9^{\circ} \mathrm{C}$ to $55,65,75,85$, and $95{ }^{\circ} \mathrm{C}$, thermal efficiency is found to be a decreasing function. The lowest thermal efficiency was above $49 \%$ at $95{ }^{\circ} \mathrm{C}$. The highest exegetic efficiency was above $46.2 \%$ at the lowest temperature of $55{ }^{\circ} \mathrm{C}$. Mohamed et al. [7] designed and fabricated solar dish concentrator with 1.6 meter diameter for water 
heating applications and for steam generation. The dish was fabricated using galvanized steel and its interior surface was covered with a reflecting layer of reflectivity up to $76 \%$. The system was equipped with a receiver (boiler) located in the focal position. The heat receiver was made of stainless steel cylindrical tube, coated with a thin layer of black paint as antireflection coating. Water is heated by passing through helical wrapped copper tubes inside the receiver cavity. It was observed that the inlet and outlet water temperatures increased during daytime between 9:30 A.M. to 1:30 P.M. because of high solar intensity. The dish was equipped with the tracking system and the water temperature was measured and found to be in the range of $80^{\circ} \mathrm{C}$ and the system efficiency was found to be $30 \%$.

In this study, a thermosyphon solar water heater with small sized parabolic trough collectors manufactured from locally available material is investigated.

\section{SYSTEM DESIGN AND MANUFACTURE}

\subsection{System design}

The idea of designing a thermosyphon system with small sized parabolic trough collectors comes from the availability of some key components at the Center for Solar Energy Research and Studies (CSERS) such as evacuated U-Tube receiver and different storage tank sizes and configurations. The aim was to produce relatively cheap system with competitive performance using local materials. The challenge was how to build the system and achieve thermosyphonic flow and generate enough heat in the storage tank. Figure 1 shows the layout of the suggested system to be manufactured and tested.

The most important part in the system is the collector and in particular the design of the parabolic surface and the material selection. Different materials from the local market were tested, and the best option selected based on the availability and durability was the Stainless Chrome plated sheet. The main critical part was the vacuum tubes (receiver) as it is very difficult to manufacture and only two different types and sizes are available. Therefore, the core point of the design and sizing the system started with the receiver size, mainly the length of the vacuum tubes. The other components were sized accordingly.

The design of the collector was accomplished by considering three parameters: The optimized collector aperture, rim angle and the receiver diameter. A rim angle of $90^{\circ}$ was preferred as it gives an optimum intercept factor and allows the depth to be the focal point [8].

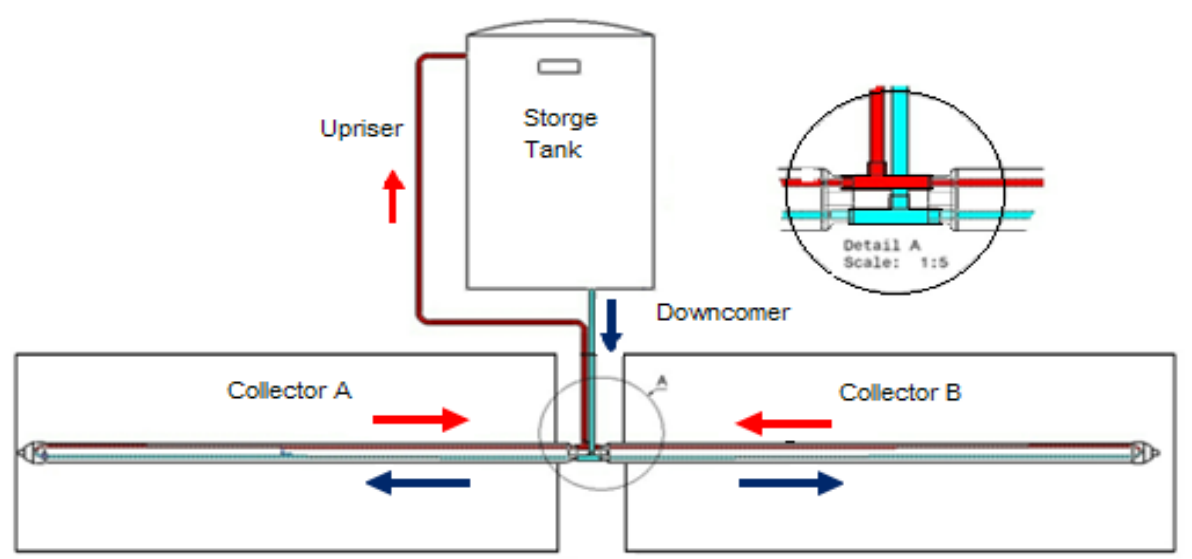

Figure (1). Schematic diagram of the designed thermosyphon solar water heater 
$(1 \mathrm{~m} \times 2 \mathrm{~m})$. After selection of $90^{\circ}$ rim angle and with the arc length $S=1 \mathrm{~m}$, the aperture width was calculated and was found to be $0.88 \mathrm{~m}$. U-turn pipe vacuum tubes available at the Center for Solar Energy Research and Studies with copper pipe diameter of $1 \mathrm{~cm}$ were used as receivers. For full details refer to [9]

The thermosyphonic flow through the collectors and the storage tank can go either in parallel or in series in the collectors according to the arrangement of the receiver pipes with the storage tank. In this study, the down flow from the storage tanks passes through the collectors in parallel as shown in Figure 1 (Black arrows).

\subsection{Collector manufacture}

After selecting the necessary parameters for designing parabolic trough collectors such as: rim angle, aperture diameter and receiver diameter, the manufacturing process was conducted using simple tools and machines. A parabola calculator program was used to draw the parabola shape with the chosen parameters. The metal structure was manufactured and the reflector sheet with dimension $(1.80 \mathrm{x}$ $1 \times 0.05) \mathrm{m}$ was bolted to the frames as shown in Figure 2. Copper pipe with $3.6 \mathrm{~m}$ length was bent as $\mathrm{U}$ shape and bonded to the Aluminum cylindrical shape receiver. Vacuum tubes from AMK-Collectra AG for DRC 10 collector were used.
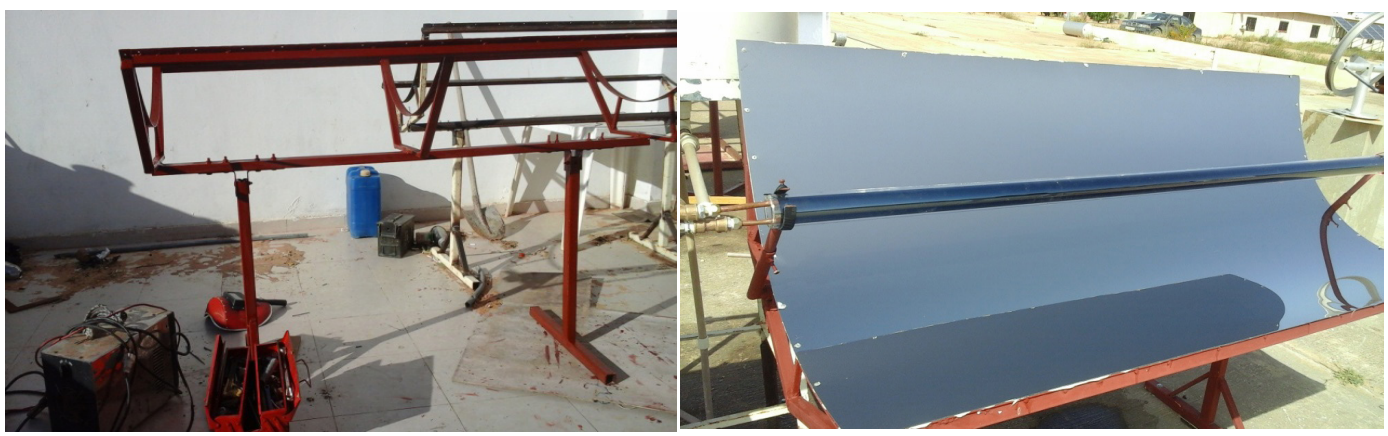

Figure (2). Metal structure of the parabolic trough collectors

The concentration ratio $(C R)$ of the collector can be calculated as:

$$
\begin{aligned}
\text { CR } & =\frac{\text { Aperture area }- \text { reciever area }}{\text { reciever area }} \\
& =\frac{1.584-0.1053}{0.2545}=5.8
\end{aligned}
$$

The manufactured parabolic trough collector has a low concentration ratio less than 5. The technical specifications of the designed collectors are listed in Table 1.

Table (1) Technical specifications of the solar collector

\begin{tabular}{|l|l|}
\hline Item & Value \\
\hline Length $(\mathrm{m})$ & 1.80 \\
\hline Aperture width $(\mathrm{m})$ & 0.88 \\
\hline Aperture area $(\mathrm{m} 2)$ & 1.584 \\
\hline Focal point $(\mathrm{m})$ & 0.22 \\
\hline
\end{tabular}

\begin{tabular}{|l|l|}
\hline Rim radius $(\mathrm{m})$ & 0.44 \\
\hline Arc length $(\mathrm{m})$ & 1.0 \\
\hline Reflector surface area & $1.80 \mathrm{~m}^{2}$ \\
\hline Absorber/glass & $360^{\circ}$ Borosilicate 3.3 \\
\hline Concentrating ratio & 5.8 \\
\hline Receiver diameter $(\mathrm{m})$ & 0.045 \\
\hline Glazing cover diameter $(\mathrm{m})$ & 0.0585 \\
\hline
\end{tabular}

\subsection{Storage tank and connecting pipes}

An open loop vertical storage tank with 170 liter capacity has been used in this system, and the support frame of the tank was manufactured according to the dimension calculated. The connecting pipes used were of the type (PEX flexible pies) with $1 \mathrm{~cm}$ diameter and covered with insulator (Arm flex) with thickness of $20 \mathrm{~mm}$. 


\subsection{Assembling thermosyphon system}

After finishing the manufacturing of the components of the desired thermosyphon solar water heater, the system was assembled as shown in Figure 3 and the technical specifications are listed in Table 2 . The system was erected in the testing area at CSESR in Tripoli Libya.

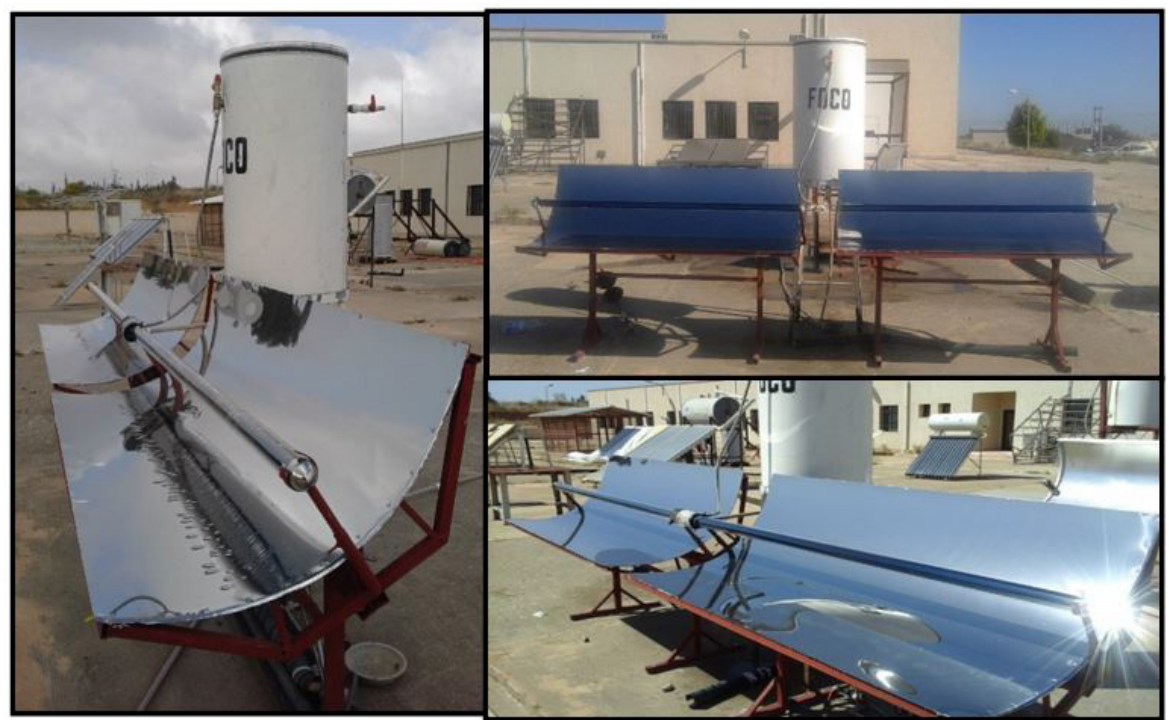

Figure (3). View of the manufactured thermosyphon solar system

Table (2). Thermosyphon main technical specifications

\begin{tabular}{|l|l|}
\hline \multicolumn{1}{|c|}{ Item } & \multicolumn{1}{c|}{ Value } \\
\hline Concentrating ratio & 5.8 \\
\hline Aperture area $\left(\mathrm{m}^{2}\right)$ & 1.58 each \\
\hline Number of collectors & 2 \\
\hline Collector from ground $(\mathrm{m})$ & 1.11 \\
\hline Tank from ground $(\mathrm{m})$ & 1.27 \\
\hline Vertical distance between collector and tank $(\mathrm{m})$ & 0.16 \\
\hline Horizontal distance between collector and tank $(\mathrm{m})$ & 0.55 \\
\hline
\end{tabular}

\section{THERMAL PERFORMANCE EVALUATION}

\subsection{Experiment setup}

The system under study consists of two concentrated collectors with (parabola shape), two vacuum tubes used as absorbers (Receiver), connecting pipes, vertical storage tank (open loop), working fluid (in this case pure water with TDS less than $160 \mathrm{ppm}$ ), and safety and pressure relief valves. For the purpose of testing the system thermal performance, the system was equipped with data logger fitted with the required measuring sensors. This practical experiment was tested under various operating conditions in order to evaluate the performance of the system.

\subsection{Testing procedure}

The procedure followed for testing the thermal performance of the system under consideration is according to the international standard ISO 9459-2 [10]. The following steps were taken for each one day test: 
- Discharging the water from the system before sunrise with at least 3 times the tank volume.

- Cleaning the reflectors and the receivers from dust.

- Making sure there are no leaks from connected pipes.

- Making sure all the devices operate well.

- Discharging the water from the tank immediately after the sunset with at least 3 times the tank volume.

\subsection{Measuring system}

The experiment was equipped with the necessary instruments to evaluate the system thermal performance. The main instruments include: inlet and outlet water temperature from the storage tank, the sensors used are thermocouples type J; ambient air temperature and relative humidity; five temperature points in the system (inlet and outlet water temperature of each collector, and at the inlet water to the tank from the collector), the sensors used are thermocouples type J; global solar radiation at the collector surface; water flow rate and volume were measured using paddlewheel 8011.All the sensors were connected to data logger to store data every 5 minutes. All the sensors are new with manufacturer accuracy.

\section{RESULTS AND DISCUSSION}

\subsection{Hot water withdrawal curves}

The hot water draw-off curves of the tested system are presented. Figure 4 shows the hot water draw-off curve with insolation over $16 \mathrm{MJ} / \mathrm{m}^{2}$ and Figure 5 shows the daily withdrawal results with insolation less than $16 \mathrm{MJ} / \mathrm{m}^{2}$.

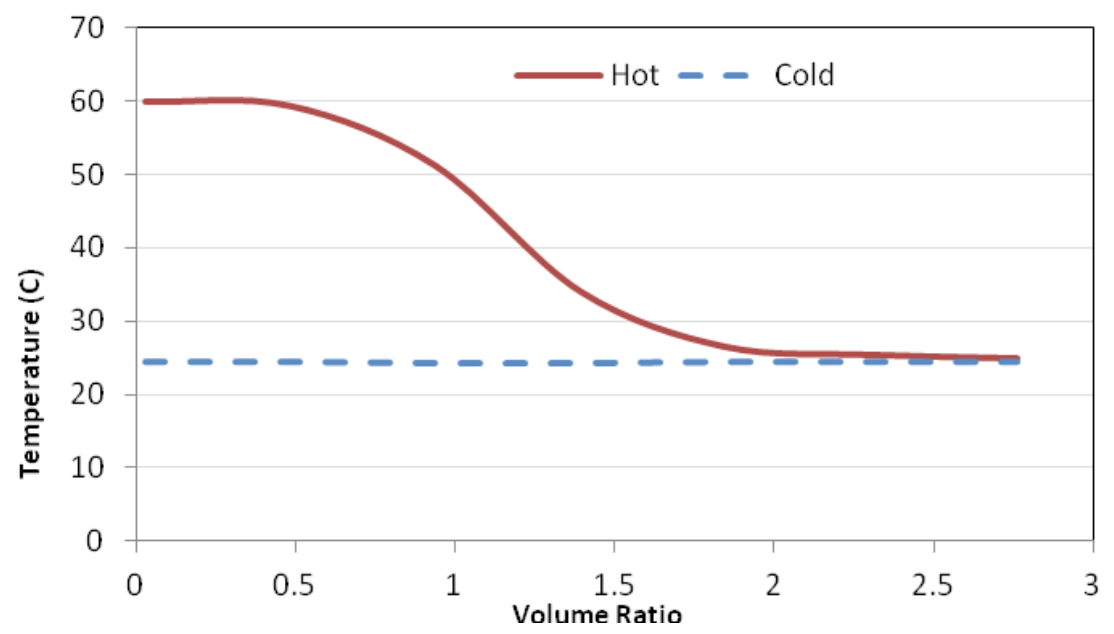

Figure (4). Hot water draw-off curve of 27-04-2016 with solar insolation $27.6 \mathrm{MJ} / \mathrm{m}^{2}$

The hot water withdrawal was continued until the difference between hot water and inlet cold water reaches $1 \mathrm{~K}$ or less, or the energy delivered by the system $(\mathrm{Q})$ equal to zero. It takes nearly two and half times the tank volume to extract the energy content from the system $(24.78 \mathrm{MJ})$ in case of high insolation $\left(27.6 \mathrm{MJ} / \mathrm{m}^{2}\right)$. While it takes only one and a half tank volume times to withdraw the energy content $(6.22$ $\mathrm{MJ})$ in case of low insolation $\left(12.82 \mathrm{MJ} / \mathrm{m}^{2}\right)$.
It is also noticed from the results for $(\mathrm{H}>16 \mathrm{MJ})$ that, the maximum hot water temperature was $73.4^{\circ} \mathrm{C}$, where the average hot water temperature is $46.09^{\circ} \mathrm{C}$ for more than two times tank volume which is 352 lit of water. For $(\mathrm{H}<16 \mathrm{MJ})$ the maximum hot water temperature was only $37.0^{\circ} \mathrm{C}$, and the bulk hot water temperature was calculated at $27.1^{\circ} \mathrm{C}$ for three times tank volume (488 Lit). 


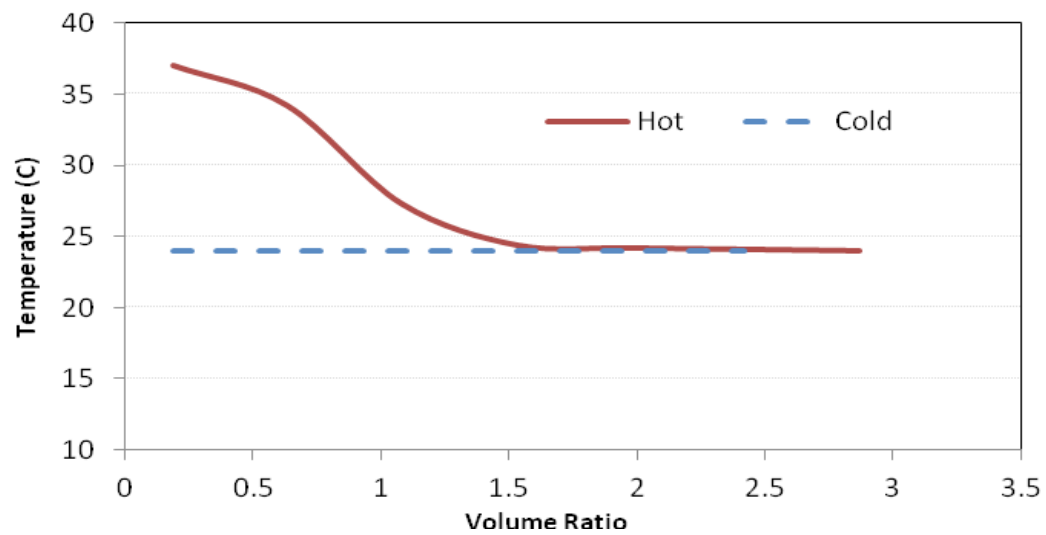

Figure (5). Hot water draw-off curve of 01-05-2016, with solar insolation $12.82 \mathrm{MJ} / \mathrm{m}^{2}$

\subsection{System performance}

According to the ISO 9459-2 at least 6 days of the experiment are needed to find the daily system performance equation, and draw the characteristics curve. 13 days of experimental results were considered for obtaining the energy system performance. A sample of the obtained results and calculation is listed in Table 3. The effect of diffuse ratio on the system performance is very obvious as the technology used is based on reflecting directed radiation. The energy system performance equation for solar-only water heater system is obtained using multi-regression correlation as follows:

$\mathrm{Q}=1.0545 \mathrm{H}-0.0327\left(\mathrm{~T}_{\mathrm{a}(\mathrm{day})}-\mathrm{T}_{\mathrm{c}}\right)+0.5846$

In addition, the equation of water temperature variation in the system under investigation is correlated as:

$\left(\mathrm{T}_{\mathrm{d}(\max )}-\mathrm{T}_{\mathrm{c}}\right)=1.6446 \mathrm{H}-0.607\left(\mathrm{~T}_{\mathrm{a}(\mathrm{day})}-\mathrm{T}_{\mathrm{c}}\right)+0.1133$

Table (3). Sample of the results obtained for one-day experiment

\begin{tabular}{|c|c|c|c|c|c|c|c|c|c|c|}
\hline & Date & $\begin{array}{l}\mathrm{T} \text { a } \\
{ }^{\circ} \mathrm{C}\end{array}$ & $\begin{array}{l}\mathrm{T} \mathrm{C} \\
{ }^{\circ} \mathrm{C}\end{array}$ & $\begin{array}{l}\text { Tout } \\
{ }^{\circ} \mathrm{C}\end{array}$ & $\begin{array}{l}\mathrm{T}_{\max } \\
{ }^{\circ} \mathrm{C}\end{array}$ & $\begin{array}{c}\mathrm{Ht} \\
\mathrm{MJ} / \mathrm{m}^{2} \\
\end{array}$ & $\begin{array}{c}\mathrm{Hd} / \mathrm{Hr} \\
\%\end{array}$ & $\begin{array}{l}\mathrm{Qu} \\
\mathrm{MJ}\end{array}$ & $\begin{array}{c}\text { Tc-Ta } \\
{ }^{\circ} \mathrm{C} \\
\end{array}$ & $\begin{array}{c}\mathrm{Td}_{\max }-\mathrm{Tc} \\
{ }^{\circ} \mathrm{C}\end{array}$ \\
\hline 1 & $27 / 04 / 2016$ & 30 & 24.58 & 37.04 & 59.4 & 27.6 & 24.2 & 24.78 & 5.42 & 34.82 \\
\hline 2 & $30 / 04 / 2016$ & 20.8 & 24.3 & 29.07 & 54.96 & 14.18 & 57.1 & 8.125 & -3.5 & 30.66 \\
\hline 3 & $01 / 05 / 2016$ & 22.18 & 24 & 27.61 & 37 & 12.82 & 61.05 & 6.22 & -1.82 & 13 \\
\hline 4 & $02 / 05 / 2016$ & 18.22 & 23.8 & 43.45 & 72.02 & 23.66 & 35.5 & 28.71 & -5.58 & 48.22 \\
\hline 5 & $03 / 05 / 2016$ & 19.65 & 23.9 & 46.09 & 73.35 & 27.67 & 17.9 & 32.69 & -4.25 & 49.45 \\
\hline 6 & $04 / 05 / 2016$ & 22.08 & 24.3 & 48.77 & 72.74 & 27.12 & 10.6 & 36.69 & -2.22 & 48.44 \\
\hline
\end{tabular}

\subsection{Reverse flow}

One of the main issues of the design and operation of thermosyphon solar water heaters is the reverse flow at night. It occurs due to the imbalance in the hot and cold water column that makes the tank as hot column while the collector is the cold column. This mechanism contributes to the heat loss from the tank and reduces the overall system efficiency. To overcome this problem the bottom of the tank should be elevated at least $20-30 \mathrm{~cm}$ above the collector height [11]. In this study, the system is designed with tank bottom to collector top distance about $16 \mathrm{~cm}$. Figure 6 shows the recorded inlet and outlet temperatures of the collector during the night 


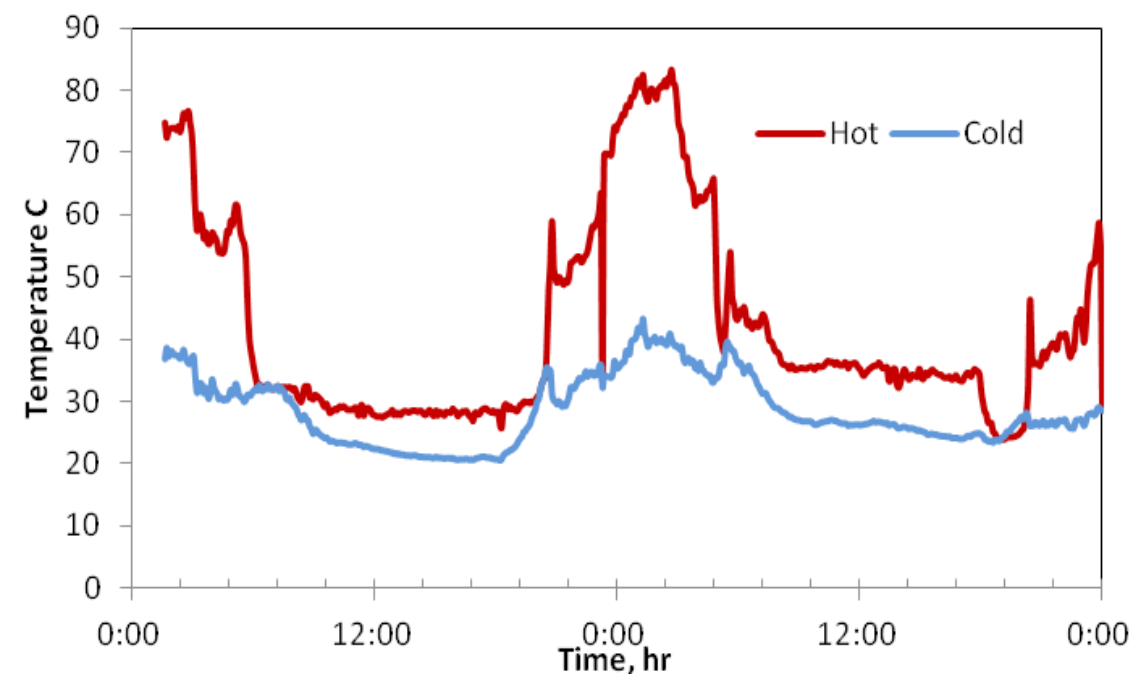

Figure (6). The temperature of the inlet and outlet of the collector for 30/31-05-2016

It is very clear from the figure that reverse flow and heat conduction occurred during the night as the temperature of the water at collector outlet is higher than the input. The collector in this case dissipated the heat to the sky by irradiative cooling. The tank should be more elevated to prevent the reverse flow and to reduce heat loss at night.

\subsection{Hot water draw-off}

Hot water load pattern has great influence on the system performance. The system performance is tested with hot water withdrawal at mid-day, with a quantity equal to one volume (exactly 165.3 liters) and the high water temperature recorded during withdrawal at mid-day was $77.4{ }^{\circ} \mathrm{C}$ as shown in Figure 7. The environmental condition during the test period is recorded for solar insolation on the collector plane $24.11 \mathrm{MJ} / \mathrm{m}^{2}$, day ambient temperature 25.7 and average wind speed of $4.01 \mathrm{~m} / \mathrm{s}$. The energy extracted from the system in the mid-day withdrawal was $16.75 \mathrm{MJ}$, and the input solar energy before mid-day was $13.91 \mathrm{MJ}$, and the energy extracted at the end of the day was 11.33 MJ with insolation of $10.19 \mathrm{MJ} / \mathrm{m}^{2}$, the total energy extracted during the day was $28.08 \mathrm{MJ}$.

The system performance was also tested for hot water withdrawn after four days of continuous operation. The draw-off was done at the end of the fourth day, and the extracted energy was $51.78 \mathrm{MJ}$ with daily output $12.95 \mathrm{MJ}$, and the accumulated solar isolation of these days was $83.08 \mathrm{MJ} / \mathrm{m} 2$ with an average daily insolation $20.77 \mathrm{MJ} / \mathrm{m}^{2}$. It can be seen from the figure that the average output energy of the system was reduced to about half of the energy with the same solar insolation. This could be attributed to the heat loss from the storage tank and to the reverse flow at night. In addition, the collector performance was reduced due to the operation at high temperature. Figure 8 shows the hot water withdrawal curve.

\subsection{Collector performance analysis}

During the course of this study, the test of collector performance according to ASHRAE 93-77 was not carried out due to the lack of capabilities. However, only temperature measurements were taken for inlet and outlet of the collectors. 


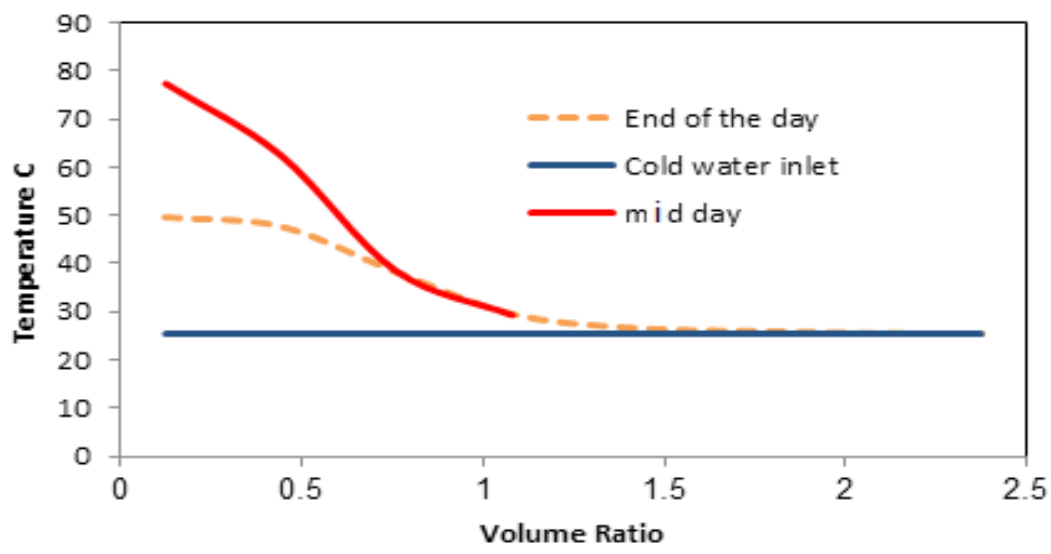

Figure (7). Hot water withdrawal curves in the mid-day and the end of the day

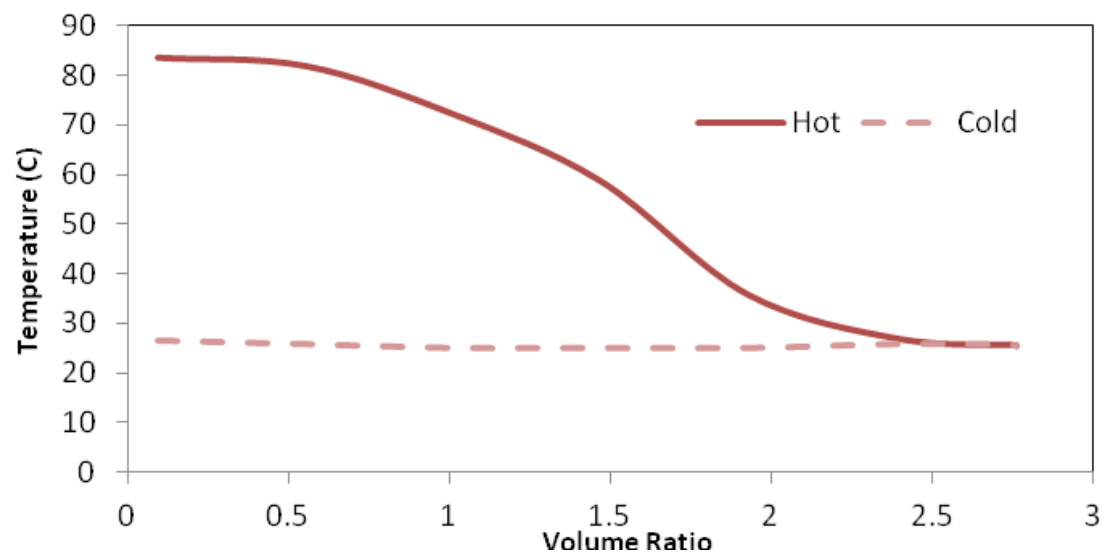

Figure (8). Hot water withdrawal for four consecutive days

\subsubsection{Collectors inlet and outlet temperature}

Four temperature sensors (thermocouples) of type $J$ were located at the inlet and outlet of each collector to measure the different temperatures of the water. Figure 9 shows the global radiation on the collector plane $(\mathrm{H})$ and the outlet temperatures of the collectors A and B during the day time (from sunrise to sunset). In addition the direct normal incidence (DNI) from the main station at the CSERS (approximately $100 \mathrm{~m}$ apart) is shown in the figure. Figure 9 indicates differences between the outlet water temperatures at collector $\mathrm{A}$ and that of collector B. These differences might be due to the shape dissimilarity because the forming of the collector shape was done manually so, the alignment may not be equal for both collectors.

In Figure 9, the sharp increase of the water outlet temperature at the beginning of the day (nearly 10:00 am) represents the required temperature to start thermosyphonic flow in the system. The flow continues whenever enough radiation is available. Figure 10 shows the water inlet and outlet temperatures of the collector A during day and night (24 hours). It is clear from the figure that the maximum outlet water temperature in the day 4-5-2016 was $77^{\circ} \mathrm{C}$, where the solar insolation was $23.66 \mathrm{MJ}$, and sky diffuse ratio was $34 \%$. 


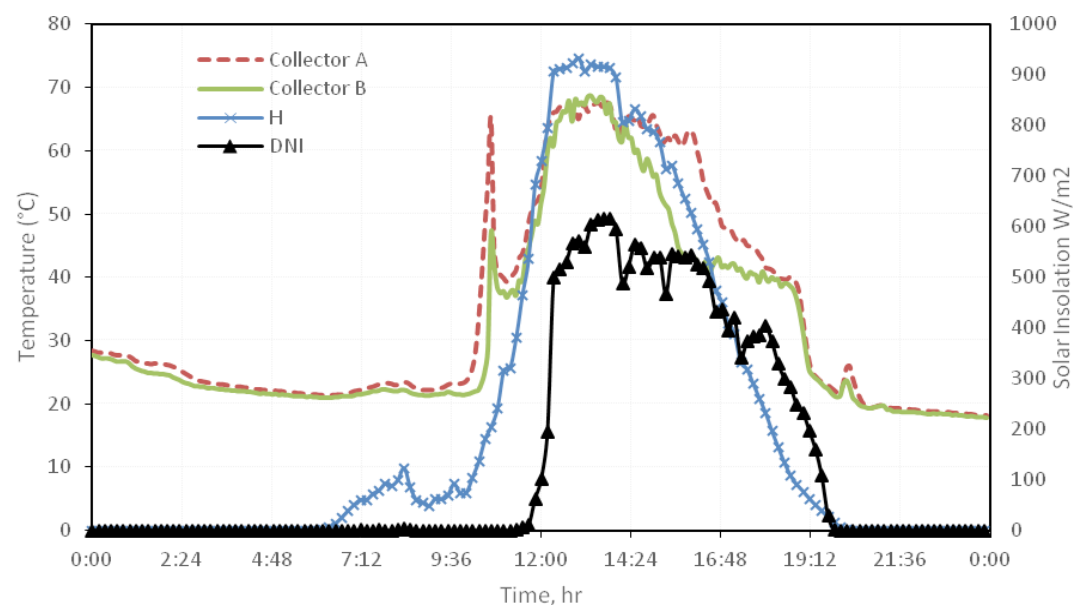

Figure (9). The daily global radiation and outlet temperature of collectors A and B (20-5-2016)

\subsubsection{Receiver heat losses}

It has been observed during the test that the system performance was reduced dramatically due to the crack of the vacuum tube of the collector receiver. It was recorded that the temperature of the outer glass of the receiver (cracked one) reached $48.3^{\circ} \mathrm{C}$ whereas at the same time the temperature of the outer glass of the un-cracked glass cover of the second collector was $26^{\circ} \mathrm{C}$. The temperature of the reflector was also recorded and it was found around $29^{\circ} \mathrm{C}$ and the ambient temperature during the day was $20.5^{\circ} \mathrm{C}$. This means the reflector surface used has good reflectivity and low absorptivity.

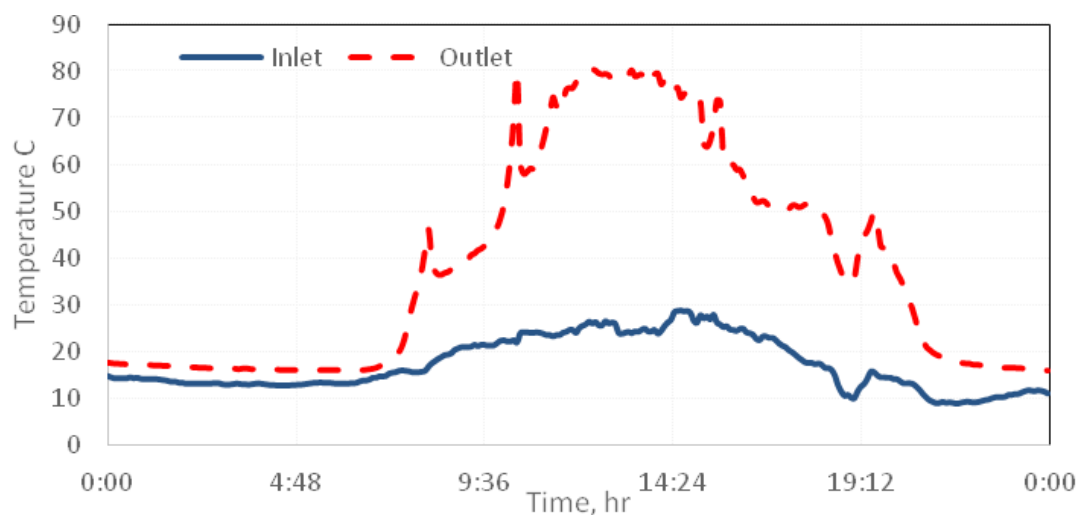

Figure (10). The inlet and outlet water temperature of the collector A during the day of 4.5.2016

\subsection{Comparison with traditional systems}

A comparison of the energy performance of the locally manufactured system with some other famous manufactured systems of nearly the same volume size was made as shown in Table 5. The data of the performance and technical specifications of the systems listed were taken from the test reports of the systems. It is clear that the manufactured system works well compared to the listed systems.

\subsection{Manufacturing cost}

One of the main purposes of this research is to reduce the capital cost of the system without compromising the performance to make it 
affordable. In this paper only a simple analysis to the manufactured cost is presented. The cost of each collector with $1.58 \mathrm{~m}^{2}$ aperture area is $207 \mathrm{~L} . \mathrm{D}$ which means the cost per unit area is $131 \mathrm{~L} . \mathrm{D} / \mathrm{m}^{2}$. This unit price depended on the local market and cannot be compared in case of mass production where the cost drops dramatically. However, this cost is still below the average range of international prices of the flat plate and vacuum tube solar collectors $(135$ - 340) L.D $/ \mathrm{m}^{2}$ respectively [12].

Table (5). A comparison between the system of this study and similar systems of different technology

\begin{tabular}{|c|c|c|c|c|c|c|}
\hline Company & $\begin{array}{l}\mathrm{Vt} \\
\text { (L) }\end{array}$ & $\begin{array}{l}\text { Loop } \\
\text { type }\end{array}$ & $\begin{array}{l}\text { Ac } \\
\left(\mathrm{m}^{2}\right)\end{array}$ & Collector type & System performance & $\begin{array}{c}\text { Q at. } \\
\mathrm{H}=20 \mathrm{MJ} / \mathrm{m}^{2} \\
\Delta \mathrm{T}=5 \mathrm{C}^{\circ}\end{array}$ \\
\hline $\begin{array}{l}\text { Sys. of this } \\
\text { study }\end{array}$ & 170 & Open & 3.16 & $\begin{array}{l}\text { Parabolic } \\
\text { trough }\end{array}$ & $\mathrm{Q}=1.0545 \mathrm{H}-0.0327\left(\mathrm{~T}_{\mathrm{a} \text { (day) }}-\mathrm{T}_{\mathrm{c}}\right)+0.5846$ & 21.51 \\
\hline Sys 1 & 170 & Integral & 1.87 & Flat plate & $\mathrm{Q}=0.79 \mathrm{H}+0.35\left(\mathrm{~T}_{\mathrm{a}(\text { day })}-\mathrm{T}_{\mathrm{c}}\right)-1.5$ & 16.05 \\
\hline Sys 2 & 170 & Open & 2.2 & Flat plate & $\mathrm{Q}=1.24 \mathrm{H}+0.27\left(\mathrm{~T}_{\mathrm{a}(\text { day })}-\mathrm{T}_{\mathrm{c}}\right)-1.6$ & 24.55 \\
\hline Sys 3 & 170 & Closed & 2.07 & Flat plate & $\mathrm{Q}=1.16 \mathrm{H}+0.4\left(\mathrm{~T}_{\mathrm{a}(\mathrm{day})}-\mathrm{T}_{\mathrm{c}}\right)-0.97$ & 24.23 \\
\hline Sys 4 & 150 & Closed & 2.22 & Evacuated T & $\mathrm{Q}=0.84 \mathrm{H}+0.35\left(\mathrm{~T}_{\mathrm{a}(\text { day })}-\mathrm{T}_{\mathrm{c}}\right)+2.22$ & 20.77 \\
\hline
\end{tabular}

\section{CONCLUSION}

This paper presents the designing and manufacturing of thermosyphon solar water heater with parabolic trough collectors using locally available materials. It has been found that stainless steel coated with chrome is the best option to be used as reflector because of its optical properties and durability. Two parabolic trough collectors were manufactured with $1.58 \mathrm{~m}^{2}$ aperture area each, which fits the proposed tank size of 170 liters.

The daily energy output equation and input/ output diagram of the system were obtained. The system has shown that the maximum recorded hot water withdrawn temperature was $73.4{ }^{\circ} \mathrm{C}$ on 3-5-2016 where the daily solar insolation on the collector plane was $27.67 \mathrm{MJ} / \mathrm{m}^{2}$ with diffuse ratio less than $18 \%$ (clear sky). Whereas, the minimum hot water withdrawn temperature was $37^{\circ} \mathrm{C}$ with daily solar insolation of $12.82 \mathrm{MJ} / \mathrm{m}^{2}$ and diffuse ratio over $61 \%$. It was very clear that the system performance decreases as the diffuse ratio increases because of the nature of concentrating technology.

The manufactured system of this study has good performance compared to some other technologies and it is competitive with other technologies with regard to cost and performance.

\section{NOMENCLATURE}

\begin{tabular}{|c|c|c|}
\hline CR & Concentration ratio & - \\
\hline DNI & Direct Normal Incidence radiation & $\mathrm{W} / \mathrm{m}^{2}$ \\
\hline $\mathrm{H}$ & $\begin{array}{l}\text { Solar insolation on the collector } \\
\text { plane }\end{array}$ & $\mathrm{MJ} / \mathrm{m}^{2}$ \\
\hline $\mathrm{T}_{\mathrm{a} \text { (day) }}$ & $\begin{array}{l}\text { Average temperature during the test } \\
\text { period }\end{array}$ & ${ }^{\circ} \mathrm{C}$ \\
\hline $\mathrm{T}_{\mathrm{c}}$ & $\begin{array}{l}\text { Average temperature of the cold } \\
\text { water }\end{array}$ & ${ }^{\circ} \mathrm{C}$ \\
\hline $\mathrm{T}_{\mathrm{a}(\max }$ & $\begin{array}{l}\text { Maximum hot withdrawal } \\
\text { temperature during the test period }\end{array}$ & ${ }^{\circ} \mathrm{C}$ \\
\hline Q & Output energy of the system & MJ \\
\hline
\end{tabular}

\section{REFERENCES}

[1]. Ottmar Edenhofer and Youba Sokona, Renewable Energy Sources and Climate Change Mitigation, Cambridge University press, 2012.

[2]. Mohamed, A.M.A., A. Al-Habaibeh and H. Abdo, An investigation into the current utilisation and prospective of renewable energy resources and technologies in Libya. Renew. Energy, 50: 732-740. 
DOI: 10.1016/j.renene.2012.07.038, 2013.

[3]. Jamil Al Asfar, Osama Ayadi and Ahmed Al Salaymeh, Design and performance assessment of a parabolic trough collector, JJMIE, Vol 8 No 1, pp 1-5, 2014.

[4]. Mohamed Chafie, Mohamed Fadhel Ben Aissa, Salwa Bouadila, Moncef Balghouthi, Abdelhamid Farhat, Amenallah Guizani, Experimental investigation of parabolic trough collector system under Tunisian climate: Design, manufacturing and performance assessment, Applied Thermal Engineering, Vol 101, pp 273-283, 2016.

[5]. Arasu V., and, Sornakumar, T., Design, manufacture and testing of fiberglass reinforced parabolic trough for parabolic trough solar collectors. Sol. Energy. 81(10), 1273-1279,2007.

[6]. Gang Pei, et al, Experimental analysis of the thermal performance of evacuated tube solar water heater systems with and without a mini-compound parabolic concentrating (CPC), Energies, 5, 911-924, 2012.

[7]. M. Mohamed, Auatf.S.Jassim, Yaseen. H. Mahmood, Mohamad A.K.Ahmed, Design and study of portable solar dish concentrator. International Journal of Recent Research and Review, Vol. III, September, 2012 .

[8]. Kalogirou, S., Eleftheriou, P., Lloyd, S. and Ward, J., Design and performance characteristics of a parabolictrough solar-collector system, Applied Energy, Vol. 47, No. 4, pp. 341-354, 1994.

[9]. Jehad M.saed, Design of thermosyphon solar water heater with parabolic trough collector, B.sc thesis, Tajoura Engineering Academy, 2016.

[10]. ISO 9459-2, Solar heating -- Domestic water heating systems -- Part 2: Outdoor test methods for system performance characterization and yearly performance prediction of solar-only systems, 1995.

[11]. Norton B. and Probert, S. D., Achieving thermal rectification in natural circulation solar energy water heaters, Applied Energy, 14, 211-225, 1983.

[12]. Center for Solar Energy Research and Studies, Previous contracts of solar water heaters from different companies in the period (2010-2014). 